\title{
Prevalence of Renal Dysfunction in ART Naïve HIV Positive Patients in Manipur, North East India
}

\author{
Wungreipam Kasar ${ }^{1}$, Suresh Singh ${ }^{2}$, N. Biplab Singh ${ }^{3}$, Ksh. Birendra Singh ${ }^{4}$ \\ ${ }^{1,2,3,4}$ Department of General Medicine, Regional Institute of Medical Sciences, Imphal, Manipur, India
}

\begin{abstract}
Objective: HIV-related renal dysfunction is a known complication. Data regarding the same is lacking in Manipur, North Eastern India. Methods: A cross sectional study of 295 ART nä̈ve HIV positive cases was done to screen for the renal dysfunction using serum creatinine, spot proteinuria, 24 hour urine protein levels, creatinine clearance and CD4 cell counts. Results: 52/295 (17.62\%) showed proteinuria.43/52 (82.7\%) had 24 hour urine protein between 500-1000 $\mathrm{mg} / \mathrm{d}$ while proteinuria $>1 \mathrm{~g} / \mathrm{d}$ was seen in 9/52 (17.3\%) cases. Lower mean CD4 count were seen in proteinuria cases, as compared to those without renal involvement $(221.7 \pm 205.72$ cells/ $\mu L$ versus $334.2 \pm 232.4$ cells/ $\mu \mathrm{L} ; p$ value $<0.0001)$. Negative correlation was found between proteinuria and CD4 count $(r=-0.489, p$ value 0.000). No correlation between proteinuria and HCV infection was seen in this study. Conclusion: Renal dysfunction was prevalent in this population. High prevalence of HIV and HIV-HCV cases along with TLE as first-line ART, warrants a more vigilant strategy for early detection and management of the renal function in HIV-positive patients undergoing treatment.
\end{abstract}

Keywor ds: CD4 cell count, creatinine clearance, HIV, proteinuria, renal dy sfunction

\section{Introduction}

About 36.7 million people worldwide have been infected with HIV.[1]Total number of people living with HIV (PLHIV) in India is 21.17 lakhs and the adult prevalence is estimated to be $0.26 \%(0.30 \%$ among male and $0.22 \%$ among female). Manipur state has the highest adult prevalence of HIV/AIDS (1.15\%) in India.[2]

Renal disease is a relatively common complication in HIV patients and prevalence is about $5-30 \%$. $[3,4]$ Several studies about the renal profile of HIV/AIDS patients have been done in other parts of India but data from the north east India is lacking.[5,6,7,8]

Spectrum of renal diseases in patients with HIV/AIDS is wide and can range from simply acid base disturbances to AKI and several glomerular lesions such as $\operatorname{Ig} \mathrm{A}$ nephropathy, memb ranous -nephropathy, membranoproliferative, mesangial proliferative, diffuse proliferative, or crescentic glo meru lonephritis. $[9,10,11]$

HIV-associated nephropathy (HIVAN) is characteristic chronic kidney diseases developing in 5-10\% HIV infected cases, and is caused by direct cytopathic effects of HIV on kidney cells and chronic inflammation mediated by cytokines. HIV viral load and the immune status of HIV positive patient is reflected best by absolute CD4 cell count. Apart from direct effects of HIV virus, other factors contributing to renal dysfunction includes drug-induced renal toxicity, opportunistic infections, hepatitis $\mathrm{C}$ infection and traditional factors like hypertension, diabetes. Adoption of tenofovir in first-line ART regimens by WHO may pose a risk for continuous rise of renal dysfunction in HIV-positive patients.[5,12,13,14]

Several studies have shown that ART prevents renal dysfunction in HIV patients but still an ongoing loss of creatinine clearance has been observed even with HIV viral suppression, which may be caused by intermittent viremia and other secondary factors in HIV positive patients.[15]
We conducted a cross sectional study to establish the prevalence of renal dysfunction in ART naïve HIV positive patients and correlate this to the CD4 cell counts.

Aims and Objects

1) To study the renal profile of ART naïve HIV/AIDS patients

2) To determine the correlation between CD4 cell count and renal dysfunction

\section{Materials and Methods}

A cross sectional study carried was carried out in the Department of Medicine (both inpatient and outpatients), Regional Institute of Medical Sciences, Imphal in collaboration with ART center of Regional Institute of Medical Sciences, Imphal from $1^{\text {st }}$ November 2016 to $31^{\text {st }}$ October 2017.

Patients of age more than 15 years who were tested HIVantibody positive (as per NACO guidelines) and had never taken ART were included in the study. Those HIV positive patients who were below 15 years of age; had pre-existing renal parenchymal disease due to diabetes, long standing hypertension, cardiac failure, chronic liver disease and collagen vascular disease and those who are taking currently or had taken ART drugs in the past, were excluded from the study.

Patients with serum creatinine $\geq 1.5 \mathrm{mg} / \mathrm{dl}$ and/or spot proteinuria $\geq 1+$ or 24 -h urinary protein $\geq 500 \mathrm{mg}$ were classified as having renal involvement. 24 hour urinary protein estimation was done in patients with spot proteinuria $\geq 1+$.

Written informed consent was obtained from all the cases before including them in the study. Detailed clinical, personal and family history was collected from the patients by means of oral questionnaire. Routine examination of blood, urine and CD4 counts were done as per NACO 


\section{Inte rnational Journal of Science and Research (IJSR) \\ ISSN (Online): 2319-7064}

Index Copernicus Value (2016): 79.57 | Impact Factor (2015): 6.391

guidelines and relevant laboratory and imaging tests were done in each case, as and when required.

Descriptive and inferential statistical analysis has been carried out in the present study. Results on continuous measurements are presented on Mean \pm SD (Min-Max) and results on categorical measurements are presented in number (\%). Significance is assessed at $5 \%$ level of significance. Chi-square and Fisher Exact test has been used to find the significance of study parameters on categorical scale between two or more groups as and when appropriate. All pvalues were two-sided. Pearson's coefficient(r) was used to see the correlation. $\mathrm{P}$ value $<0.05$ was significant.

The Statistical software namely SPSS 21 and R environment ver.3.2.2 were used for the analysis of the data.

\section{Infor med Consent}

Informed written consent was taken from all the participants. Privacy and confidentiality was strictly maintained in all the cases by coding the patients.

\section{Ethics Approval}

Ethical approval was obtained from the Research Ethics Board, RIMS, Imphal before beginning of the study.

\section{Results and Observation}

The present study included 295 HIV positive patients. Maximu m number of patients were in age group 31-40 years (113 cases, $37.31 \%$ ). The mean age was 36.3 years (range 18 - 67 years). Most of the patients belonged to reproductive age group. $200(67.79 \%)$ were male and 105 (35.59\%) were females, of which 17 were pregnant.

Out of 295 cases, $52(17.62 \%)$ had proteinuria on urine examination. The mean $24-\mathrm{h}$ urinary protein in proteinuria cases was $897.05 \pm 402.03 \mathrm{mg} /$ day. $43(82.7 \%)$ cases had 24 $\mathrm{h}$ urine protein between $500-1000 \mathrm{mg} /$ day, while proteinuria of $>1 \mathrm{~g} /$ day was found in $9(17.3 \%)$ cases.

Table 1: Distribution of proteinuria

\begin{tabular}{|c|c|c|}
\hline Spot proteinuria & No. of cases & $\begin{array}{c}\text { Percentage (\%) } \\
(\mathrm{n}=52)\end{array}$ \\
\hline$\geq 1+$ & 43 & 82.69 \\
\hline$\geq 2+$ & 5 & 9.61 \\
\hline$\geq 3+$ & 4 & 7.69 \\
\hline
\end{tabular}

The mean serum creatinine of study population was $1.04 \pm 0.95 \mathrm{mg} / \mathrm{dl}(95 \% \mathrm{CI}=0.91-1.85)$, while mean blood urea levels were $55 \pm 34.6 \mathrm{mg} / \mathrm{dl}(95 \% \mathrm{CI}=52.85-68.47) .18$ out of 295 patients had renal dysfunction with serum creatinine $\geq 1.5 \mathrm{mg} / \mathrm{d} 1.123 / 295 \quad(41.7 \%)$ had renal dysfunction, when creatinine clearance $<90 \mathrm{ml} / \mathrm{min} / 1.73 \mathrm{~m}^{2}$ was considered and the mean serum creatinine level in them was $2.65 \pm 1.21 \mathrm{mg} / \mathrm{dl}(95 \% \mathrm{CI}=1.26-3.43)$ while mean blood urea levels were found to be $87.25 \pm 37 \mathrm{mg} / \mathrm{dl}(95 \%$ $\mathrm{CI}=63.4-91.0)$.
Table 2: Distribution of creatin ine clearance

\begin{tabular}{|c|c|c|}
\hline $\begin{array}{c}\text { Creatinine clear ance } \\
\left(\mathrm{ml} / \mathrm{min} / 1.72 \mathrm{~m}^{2}\right)\end{array}$ & Number of cases & $\begin{array}{c}\text { Percentage (\%) } \\
(\mathrm{n}=295)\end{array}$ \\
\hline$\geq 90$ & 172 & 58.3 \\
\hline $60-89$ & 83 & 28.3 \\
\hline $30-59$ & 31 & 10.5 \\
\hline $15-29$ & 7 & 2.37 \\
\hline$<15$ & 2 & 0.67 \\
\hline
\end{tabular}

Among the cases with proteinuria, $3(5.76 \%)$ patients were HCV-Antibody positive. Association between proteinuria and HCV was statistically not significant ( $p$ value $=0.389$ ). Decreased creatinine clearance $\left(<90 \mathrm{ml} / \mathrm{min} / 1.73 \mathrm{~m}^{2}\right)$ was found in 56/189 (29.63\%) cases with CD4 count $>200$ cells $/ \mu \mathrm{L}$ and in $67 / 106(63.2 \%)$ cases with CD4 count $\leq 200$ cells $/ \mu \mathrm{L}$ ( $\mathrm{p}$ value $=0.0102$ ). The mean CD4 cell count in patients with renal involvement was $221.7 \pm 205.72$ cells $/ \mu \mathrm{L}$ and in those without renal involvement was 334.2 \pm 232.4 cells $/ \mu \mathrm{L}$ ( $\mathrm{p}$ value $<0.0001$ ).

Negative correlation was found between albuminuria and CD4 cell count $(r=-0.489$, $\mathrm{p}$ value $=0.000)$.

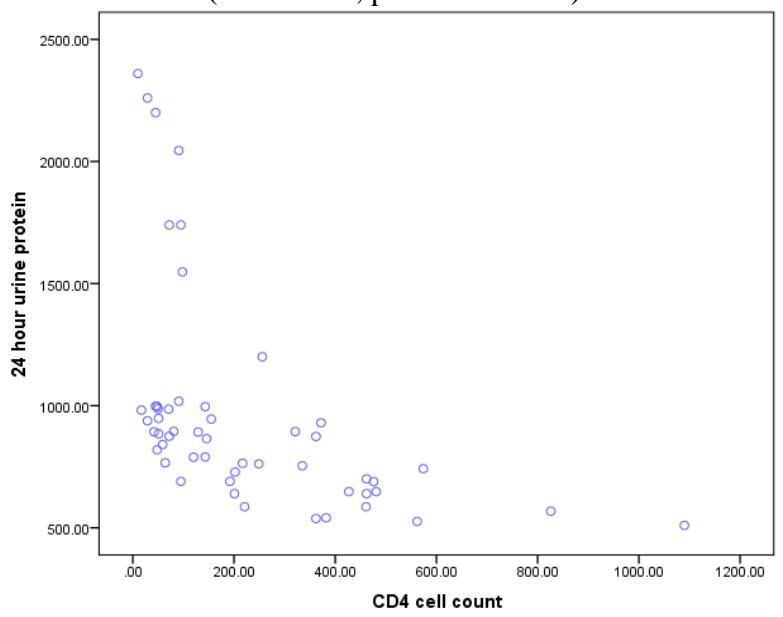

Figure 1: Correlation between 24 hour urinary protein and CD4 cell counts.

A positive correlation existed between creatinine clearance and $C D 4$ cell count $(r=0.225$, $p$ value $=0.001)$.

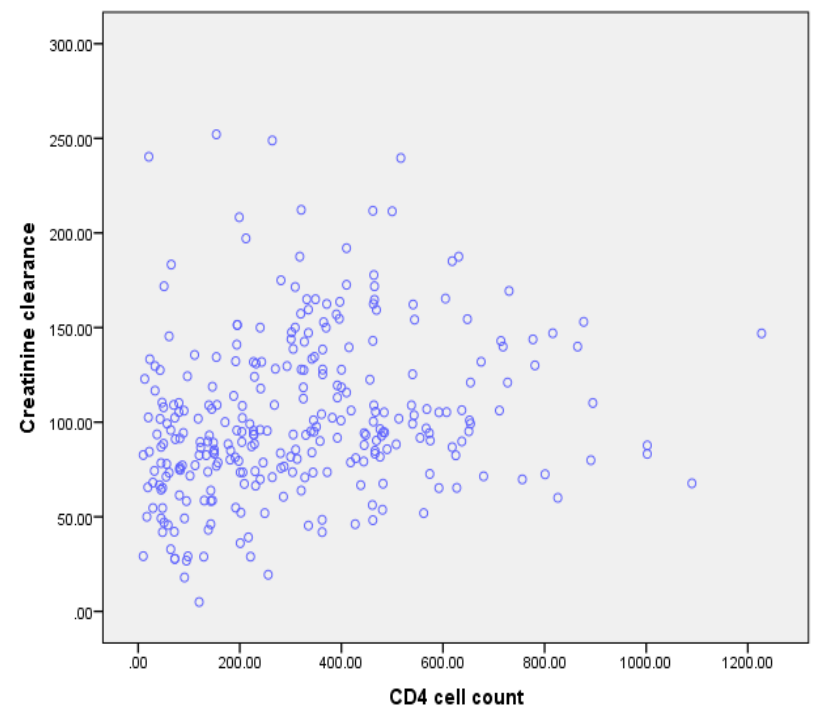

Figure 2: Corre lation between creatinine clearance and CD4 cell counts 


\section{Discussion}

In our study 52/293 (17.74\%) patients had proteinuria on urinalysis. This is consistent with the study done by Varma PP et al[6] who reported 25/142 (17.6\%)to have proteinuria. Similarly, Gupta V et al[5] reported that 58/392 (14.79\%) in ART naïve cases to have proteinuria. While Janakiraman $\mathrm{H}$ et al[9] reported 29/104 (27\%) cases and Prakash J et al[3] reported $112 / 293(38.2 \%)$ cases to have proteinuria. The discrepancy in the later two studies was probably due to inclusion of HIV patients already on ART and also due to difference in sample size. The mean 24 hour urinary protein in the cases with spot proteinuria in our study was $897.05 \pm 402.03 \mathrm{mg} /$ day. However, the study of Gupta V et al[5] showed that mean 24 hour urinary protein in cases with spot proteinuria was $1561 \pm 906 \mathrm{mg} /$ day. The difference with the presence study might be due to inclusion of patients on ART in his study. No patient in present study had nephrotic range proteinuria. Proteinuria $>1 \mathrm{~g} / \mathrm{day}$ was found in $9(17.3 \%)$ cases in the present study, which was similar to Prakash J et al[3] who found $16 / 112(14.2 \%)$ patients to have proteinuria $>1 \mathrm{~g} /$ day.

Among cases of renal dysfunction whose creatinine clearance $\leq 60 \mathrm{ml} / \mathrm{min} / 1.73 \mathrm{~m}^{2}$, mean seru m creatinine in the present study was $2.87 \pm 3.01 \mathrm{mg} / \mathrm{dl}$. The study done by Gupta $\mathrm{V}$ et al[5] showed a higher mean seru m creatinine of $4.60 \pm 3.17 \mathrm{mg} / \mathrm{dl}$.

Our study depicted a negative correlation between CD4 count and albuminuria, which was statistically significant and was in agreement with study results of Janakiraman $\mathrm{H}$ et al[9].

Present study showed a positive correlation between CD4 counts and creatinine clearance in the study population. Out of 106 cases with CD4 counts $\leq 200$ cells/ $\mu \mathrm{L}, 25$ (23.58\%) cases had renal dysfunction. In the study done by Mulenga LB et al[13], renal dysfunction was assessed by CockcroftGault formula and $33.5 \%$ patients had renal insufficiency. When Patients with CD4+ cell counts $\geq 200$ cells $/ \mu \mathrm{L}$ were more likely to have reduced creatinine clearance compared to those with CD4+ counts between $50-199$ cells/ $\mu \mathrm{L}$ (ARR $=1.2,95 \% \mathrm{CI}: 1.1-1.2)$ and those with CD4+ counts less than 50 cells $/ \mu \mathrm{L}(\mathrm{ARR}=1.4,95 \%$ CI: 1.4-1.5). Similar results were reported by Atta MG et al[17], that HIV associated nephropathy cases had a significantly higher creatinine $(8.2 \mathrm{mg} \%$ versus $2.5 \mathrm{mg} \%)$ and a lower CD4 cell counts $(158 / \mu \mathrm{L}$ versus $349 / \mu \mathrm{L} ; \mathrm{p}<0.01)$. There study also depicted that IVDU, HCV and hypertension were not associated with HIVAN.

Rossi C et al[14] reported that higher CKD incidence rate among HCV co-infected than HIV mono-infected patients (26.0 per 1000 PYFU vs. 10.7 per 1000 PYFU) which was contrary to the findings of present study and the study done by Atta MG et al[17]. Even with high prevalence of HCV infection in Manipur, present study didn't show significant association between HCV infection and renal dysfunction in HIV patients. The reason might be that previous study was a cohort study while later two are cross sectional studies, which might not assess the impact of $\mathrm{HCV}$ on renal dysfunction. However the domain of renal dysfunction in
HIV-HCV co-infection needs an elaborative study in present study set up due to high prevalence of $\mathrm{HCV}$ infection in Manipur.

\section{Future Scope}

HIV infection appears to be a risk factor for developing chronic kidney disease. Even in patients with normal serum creatinine, the presence of proteinuria may be an early indicator of chronic kidney disease. If initial urine analysis results are normal, annual follow-up urine analysis are recommended to screen for newly developed kidney damage for high risk groups- diabetes, hypertension, hepatitis C virus co-infection, high HIV-RNA levels or CD4 counts $<200$ cells $/ \mu \mathrm{L}$. Main limitations of the study were that firstly HIV viral load was not performed in the cases and renal biopsy was not done in the cases with proteinuria. The domain of renal dysfunction in HIV-HCV co-infection needs an elaborative study including HCV viral load and genotyping to give better insight. However, HCV viral load was not done due to limitation of study set up and financial constraints. Finally a larger sample size with follow up study is needed for more robust results.

\section{Conclusion}

Present study was conducted in the Manipur state of Northeastern India, having highest prevalence of HIV/AIDS and a high prevalence of HCV infection in India. The study included ART naïve patients with HIV/AIDS and depicted that renal dysfunction is quite prevalent in the study population. Renal dysfunction was more common in the patients having lower CD4 counts. Study showed a significant negative correlation between $\mathrm{CD} 4$ counts and albuminuria. It is recommended to use proteinuria as a routine screening tool in high risk HIV cases, especially HIV-HCV co-infection and HIV with low CD4 counts, for early detection and management of renal dysfunction. Such patients might require more frequent follow up than recommended by NACO guidelines. However a larger prospective study with a larger sample size is needed to formulate the management strategies in order to reduce the morbidity and mortality in the patients of HIV induced renal dysfunction.

\section{Conflicts of Interest}

There are no conflicts of interest regarding this study.

\section{Financial Support}

None received.

\section{References}

[1] UNAIDS: Fact sheet- Latest statistics on the status of the AIDS epidemic. Available at http://www.unaids.org/en/resources/fact-sheet. Accessed December 9, 2017.

[2] NACO. Annual report 2016-17. Available at http://naco.gov.in/documents/annual-reports. Accessed Dece mber 9,2017.

\section{Volume 6 Issue 12, December 2017}




\title{
Inte rnational Journal of Science and Research (IJSR) \\ ISSN (Online): 2319-7064
}

Index Copernicus Value (2016): 79.57 | Impact Factor (2015): 6.391

[3] Prakash J, Ganiger V, Prakash S, Sivasankar M, Sunder $S$, and Singh U. Kidney Disease in Human Immunodeficiency Virus-seropositive Patients: Absence of Human Immunodeficiency Virus-associated Nephropathy was a Characteristic Feature. Indian J Nephrol. 2017;27(4):271-6.

[4] Calza L, Vanino E, Magistrelli E, Salvadori C, Cascavilla A, Colangeli V, et al. Prevalence of renaldisease within an urban HIV-infected cohort in Northern Italy. Clin Exp Nephrol. 2014;18(1):104-12.

[5] Gupta V, Gupta S, Sinha S, Sharma SK, Dinda AK, Agarwal SK, et al. HIV associated renal disease: A pilot study from North India. Indian $\mathbf{J}$ Med Res. 2013;137(5):950-6.

[6] Varma PP, Prasher PK, Deshpande GU, Mani NS, Nema SK, Sayal SK. Spectrum of renal lesionsin HIV patients. J Assoc Physicians India. 2000;48(12):1151-4.

[7] Singh JP, Kohli S, Jamwal S, Sharma R, Hamid S, Raina $S$, et al. Prevalence of microalbuminuria and proteinuria in patients of HIV/AIDS in Jammu. JK Sci. 2011;13(2):84-8.

[8] Gupta SK, Mamlin BW, Johnson CS, Dollins MD, Topf JM, Dubé MP. Prevalence of proteinuria and the development of chronic kidney disease in HIV-infected patients. Clin Nephrol. 2004;61(1):1-6.

[9] Janakiraman $\mathrm{H}$, Abraham G, Matthew M, kuruvilla S, Panikar V, Solomon S, Kumaraswamy, Seshan SV, Lesley N. Correlation of CD4 Counts with Renal Disease in HIV Positive Patients. Saudi J Kidney Dis Transplant. 2008;19(4):603-7.

[10] Szc zech LA, Gupta SK, Habash R, Guasch A, Kalay jian $\mathrm{R}$, Appel R, et al. The clinical epidemiology and course of the spectrum of renal diseases as sociated with HIV infection. Kidney International. 2004;66(3).1145-52.

[11] Vali PS, Ismal K, Gowrishankar S, Sahay M. Renal disease in human immunodeficiency virus - Not just HIV associated nephropathy. Indian J Nephrol. 2012; 22(2): 98-102.

[12] Msango L, Downs JA, Kalluvya SE, Kidenya BR, Kabangila R, Johnson Jr. WD, et al. Renal Dysfunction among HIV-Infected Patients Starting Antiretroviral Therapy in Mwanza, Tanzania. AIDS. 2011;25(11): 1421-5.

[13] Mulenga LB, Kruse G, Lakhi S, Cantrell RA, Reid SE, Zulu I, et al. Baseline renal insufficiency and risk of death among HIV-infected adults on antiretroviral therapy in Lusaka, Zambia. A IDS. 2008; 22(14): 18217.

[14] Rossi C, Raboud J, Walmsley S, Cooper C, Antoniou $\mathrm{T}$, Burchell AN, et al. Hepatitis C co-infection is associated with an increased risk of incident chronic kidney disease in $\mathrm{HIV}$-infected patients initiating combination antiretroviral therapy. BMC Infectious Diseases. 2017; 17:246-56.

[15] Choi AI, Shlipak MG, Hunt PW, Martin JN, Deeks SG. $\mathrm{HIV}$-infected persons continue to lose kidney function despite successful antiretroviral therapy. AIDS. 2009;23(16): 2143-9.

[16] Atta MG, Gallant JE, Rahman MH, Nagajothi N, Rascusen LC, Scheel PJ, et al. Antiretroviral therapy in the treatment of HIV-associated nephropathy. Nephrol Dial Transplant. 2006;21(10):2809-13.
[17] Atta MG, Choi MJ, Longenecker JC, Hay mart M, Wu J, Nagajothi N, et al. Nephrotic range proteinuria and CD4 count as non-invasive indicators of HIV associated nephropathy. Am J Med. 2005;118(11):1288- e21-e26.

\section{Author Profile:}

Dr. Wungreipam Kasar, MD (Internal Medicine)- Senior Resident, Department of General Medicine, Regional Institute of Medical Sciences, Imphal, Manipur, India.

Dr. Suresh Singh- Post graduate trainee (Third y ear) - Department of General Medicine, Regional Institute of Medical Sciences, Imphal, Manipur, India.

Dr. N. Biplab Singh, MD (Internal Medicine)- Professor, Department of General Medicine, Regional Institute of Medical Sciences, Imphal, Manipur, India.

Dr. Ksh. Birendra Singh, MD (Internal Medicine)- Professor, Department of General Medicine, Regional Institute of Medical Sciences, Imphal, Manipur, India.

Volume 6 Issue 12, December 2017

\author{
www.ijs r.net
}

Licensed Under Creative Commons Attribution CC BY 